УДК 336.14:330.856

(C) 2014

Чеберяко О. В., кандидат економічних наук, доктор історичних наук

Київський національний університет ім. Тараса Шевченка

\title{
ВПЛИВ ГРОШОВОЇ РЕФОРМИ 1920-х РОКІВ НА БЮДЖЕТНІ ВІДНОСИНИ В УКРАЇНСЬКІЙ СРР
}

\author{
Рецензент - доктор економічних наук, професор, илен-кореспондент НААНУ П. М. Макаренко
}

Становлення та функиіонування радянської бюджетної системи в УСРР у 1920-ті рр. було неможливим без грошової реформи, а ї̈ здійснення у 19221924 рр. сприяло організаційно-функціональному впорядкуванню бюджетної системи, формуванню сталих показників дохідної $і$ видаткової частин державного та місиевих бюджетів, інакше - так званого твердого бюджету. Показано, щзо під кутом зору бюджетного фінансування основне навантаження протягом 1921-1924 рр. узяв на себе радянський знак, тобто гроші державної скарбниці. Радянський знак навіть охороняв червінець від знеиінення в період його запровадження як нової грошової одиниці. Тому, визначаючи вплив грошової реформи на бюджетний прочес, слід брати до уваги всі стадї грошової реформи та співвідношення довоєнного рубля й так званого товарного, умовного золотого рубля. В умовах утвердження твердої валюти - червінця - для стабілізації бюджетної системи $i$ бюджетних відносин важливо було запобігти знеиіненню, унеможливити від ролі емісійного засобу. Для ичього необхідно було уникати емісії в бюджетних доходах, економно використовувати бюджетні видатки, відповідально ставитися до бюджетного планування, ретельно розглядати фінансові джерела.

Ключові слова: УСРР, НЕП (нова економічна політика), бюджетна система, твердий бюджет, гроші, грошова реформа, грошова система, грошова маса, червінещь, кількісна теорія громей.

Постановка проблеми. Організаційне та функціональне становлення радянської бюджетної системи і бюджетних відносин в УРСР відбувалося у 1920-ті роки. Запровадивши НЕП i, розпочавши створення бюджетної системи, радянська влада змушена була здійснити грошову реформу. Необхідність ії проведення диктувалася глибокою і затяжною економічною кризою, розбалансованою фінансовою системою, поверненням в умовах НЕПу до товарно-грошових відносин. Політика «воєнного комунізму», яку ще до непу практикували більшовики, повністю ігнорувала гроші, ринок, товарне виробництво. Суспільству, за визначенням Л. М. Юровського, було запропоновано принцип «зв'язаного споживання», тобто розподілу продуктів між споживачами не за їхнім вільним вибором, а за системою вручення продовольчих пайків. Подібний принцип розвитку економіки, на переконання ученого, нівелював основні функції грошей (обмінну, платіжну, вартісну тощо), а політика воєнного комунізму насаджувала «казармений соціалізм» [25, с. 119]. Комуністичний метод прямого продуктообміну, запроваджений більшовиками, занедбав класичні форми товарного виробництва та грошового обігу, тому процвітав «чорний» ринок, лихварство, «мішечництво». Економічно-господарські експерименти радянської влади вплинули на соціальну галузь, спричинили натуралізацію бюджету, його хронічний дефіцит. Бюджетна система в умовах розбалансованої кредитно-банківської системи та грошової одиниці фактично зникла, - натомість діяв принцип продрозверстки у фінансовій галузі, коли установи їздили до Москви за ресурсами. Заручником «червоногвардійського наступу на капітал» стали бюджет, мільйони громадян, які працювали у бюджетних установах, господарські та соціокультурні галузі суспільства. Без стабільної грошової одиниці неможливо було сформувати «твердий бюджет», тобто реальні доходи і прогнозовані видатки. Політичне керівництво шукало виходу з катастрофічного становища, яке створило власними руками. Вихід із нього мав ознаки системної реформи, тактика і стратегія якої були закладені у новій економічній політиці. Неп передбачав відновлення грошової системи за класичним зразком капіталістичних країн, повернення до товарно-грошового обігу, допускав існування приватного сектора в торгівлі, промисловості й сільськогосподарському виробництві, децентралізацію управління економічним життям суспільства, відновлення зовнішньо економічних зв'язків, кредитно-банківської системи. 10 жовтня 1921 року Всеросійський ЦВК і 4 січня 1922 p. ВУЦВК прийняли декрет «Про заходи щодо впорядкування фінансового господарства». Основну ж роль в оздоровленні фінансів мав відіграти Державний банк, який було заново засновано 12 жовтня 1922 року. 


\section{EKOHOMIKA}

\begin{abstract}
Аналіз останніх досліджень і публікацій, у яких започатковано розв'язання проблеми. Історія здійснення грошової реформи загалом висвітлювалася в історично-економічній літературі. У 1920-ті pр. досить виразно виокремлювався ії вплив на бюджетні відносини. Радянська економічна наука оминала цей аспект, хоча розкривала основні віхи впровадження нової грошової одиниці - червінця, деномінацію радянських знаків, їх заміну новими грішми. Зокрема короткий огляд питання спочатку було зроблено в синтезуючому виданні «Історія народного господарства УРСР» [3, с. 195-197]. Сучасні науковці як в історичних, так і економічних працях також не пов'язують грошову реформу з бюджетними процесами [8]. Зрозуміло, що цей напрям дослідження не знайшов належного висвітлення в історичних розвідках із фінансово-економічних змін в УСРР періоду непу [6].
\end{abstract}

Мета дослідження полягає в тому, щоб дослідити суть грошової реформи в 1922-1924 pр. та показати ії̈ вплив на функціонування бюджетної системи й стабілізацію бюджетних відносин в Українській СРР у 1920-ті роки.

Нашим завданням буде дослідити низку вагомих джерел, зміст яких дасть змогу проаналізувати організаційно-технічну та функціональноекономічну складові реформи.

Результати дослідження. 3 перших днів свого існування радянська влада сприймала роль грошей буквально: збільшувала грошову масу, сподіваючись на нормалізацію становища. Проте така фінансова політика лише знецінила роль i значення грошей, призвівши до подорожчання основних продуктів. За 1917-1922 рр. фінорганами було випущено 17,5 трильйонів крб паперових грошей радянського зразка [23, арк. 1]. Лише за першу половину 1920 р., за оцінкою голови фінансового комітету ЦК РКП(б) та члена колегії Наркомфіну РСФРР Є. Преображенського, випустили паперових грошей значно більше, ніж у 1915-1919 роках [9, с. 72]. Емісія, тобто збільшення кількості паперових грошей в обігу, сприймалася ним як фінансовий засіб «відчуження» частини доходів дрібної буржуазії на користь «фонду соціалістичного нагромадження» $[9$, с. 75]. Відомий американський учений у галузі фінансів і теорії грошей Джон Кейнс, книга якого була перекладена й видана російською мовою у 1925 р. [5], також вважав штучну емісію у радянській Росії «засобом оподаткування» заможних груп суспільства. Представник партійно-радянської номенклатури I. I. Рейнгольд, який працював у фінансових установах, 3'ясовуючи підсумки «фінансового оздоровлення радянської республіки» у 19221924 рр., зазначав: «...здорова валюта пов'язана міцними узами зі здоровим державним бюджетом, позаяк дефіцитність бюджету змушує державу вдаватися до покриття цього дефіциту, крім нормальних джерел, якими $\epsilon$ кредитні операції, до таких надзвичайних ресурсів, як емісія, а це означає прибування нової хвилі паперових грошей до тієї маси, яка уже є в обігу, подальше знецінення паперово-грошової маси і повторення цього циклу на основі розширеного використання емісії як бюджетного ресурсу» [10, с. 35]. Емісія, за його підрахунками, становила у $1921 / 22$ p. $35 \%$, y $1922 / 23$ p. $-27 \%$, y $1923 / 24$ p. $-10 \%$.

Крім того, грошова емісія (монетизація) спричинює загрозу інфляції та погіршує стан грошового обігу. Внаслідок монетизації дефіциту бюджету держава може отримати сеньйораж - дохід від друкування та карбування грошей. Він виникає, коли темпи зростання грошової маси перевищують темпи зростання реального ВВП, наслідком чого $є$ зростання середнього рівня цін. Така емісія повинна супроводжуватися жорстким контролем за використанням випущеної готівки. За світовими стандартами, обсяг емісії допускається в межах 2-3 \% бюджетного дефіциту до ВВП.

Бюджет 1924/25 р., як вважав I. I. Рейнгольд, склали так, що не було «...більше потреби вдаватися до емісії, як до способу покриття бюджетного дефіциту. Епоха емісійного господарства завершилася» $[10$, с. 36$]$. Однак це був оптимістичний висновок, позаяк протягом другої половини 1920-х рр. Держбанк та Наркомфін СРСР продовжували використовувати емісійні методи наповнення бюджету. Хоча на сьогодні, згідно з п. 6 ст. 15 «Бюджетного Кодексу України», емісійні кошти Національного банку України не можуть бути джерелом фінансування дефіциту Державного бюджету України [1].

Фінансове оздоровлення економіки за рахунок емісії - не кращий засіб, але його використовували для покриття дефіциту бюджету та подолання неймовірного зростання цін на товари широкого вжитку. Водночас, виходячи $з$ кількісної теорії грошей Д. Кейнса, їх наявність залежала саме від рівня цін. Якщо споживання і виробництво товарів лишаються незмінними, то за умови збільшення цін і зарплати у два рази - необхідно було вдвоє збільшувати грошову масу. У 1921/22 р. кількість грошових знаків, за підрахунками професора Л. Яснопольського, збільшилася у 203 рази, а протягом наступного 1922/23 господарського року - у 23 рази. 


\section{EKOHOMIKA}

Отже, емісійна тенденція зменшувалась, проте тривала [26, с. 2-3]. Це стосувалося не лише старих зразків радянських знаків, а також і нової радянської валюти - червінця, випущеного у листопаді 1922 р. для комерційно-торгових операцій, а «...не для бюджетних потреб». Наприкінці 1922 р. грошова маса складалася винятково 3 радянських знаків, тому використання червінця як засобу покриття дефіциту бюджету вважалося неприпустимим явищем. Дивно, але робота банківського верстата, який штампував паперові гроші, сприймалася тоді цілком нормально, а декому вважалася й необхідною. «Емісія, - зазначав у 1923 р. О. Новицький, - мала чисто політичне значення. Вона знецінила грошові капітали буржуазії та куркульства і розчистила грунт державі для фінансових реформ у той момент, коли вони знадобилися» [7, с. 4]. Перший бюджет 1922/23 р., за його підрахунками, мав $41 \%$ емісійного наповнення. Отже, емісія була майже основним засобом подолання бюджетного дефіциту до початку грошової реформи, виконувала регулятивну функцію і протягом здійснення реформи у 1922-1924 роках.

Грошова реформа мала організаційнотехнічну та функціонально-економічну складові. Для з'ясування факторів впливу на бюджетну систему більше значення мають функціональні наслідки реформи грошової одиниці, ніж звичайна заміна радянських знаків на червінці. Першим кроком на шляху реформування грошової системи була деномінація (від лат. denominatio - найменування, позначення - зміна номінальної вартості грошових знаків із метою стабілізації валюти чи спрощення розрахунків. Деномінація відбувається шляхом обміну за встановленим співвідношенням (10:1, 100:1 і т. ін.) старих грошових знаків на нов), що розпочалася 3 листопада 1921 року. Вона уніфікувала «державні грошові знаки» зразка 1922 р., запропонувавши за 1 крб. 10 тис. крб. попередніх випусків. Друга деномінація здійснювалася за курсом: 100 крб. зразка 1922 р. дорівнювали одному карбованцю 1923 р., названого тоді «мільйоном» [25, c. 128]. Деномінація спростила касово-розрахункові операції, проте збільшила емісію у 30-35 разів [26, с. 2-3], тобто не вирішувала проблеми дефіциту бюджету, i, тим більше, «твердого» бюджету. Необхідно було шукати нову форму вартісного виміру, тобто нову грошову одиницю, позаяк «...без стабільної грошової одиниці - немає реального бюджету» [25, с. 194]. У листопаді 1921 р. Раднарком РСФРР вимагав, аби бюджет був встановлений у довоєнних карбованцях. Однак виявилося, що чинні ціни не були тотожні реальним довоєнним цінам на товари, i, тим більше, ціні золота на внутрішньому ринку 1920-х років. Пересічна ціна на товари у 60 разів була вищою від їх вартості у 1913 році. Тому для отримання ціни будь-якого товару в довоєнних карбованцях треба було середню ціну в радянських знаках розділити на 60 000. Так виник індекс товарних цін. Державні доходи і видатки на 1922/23 р. відбувалися у золотих карбованцях [11], але не в реальних фізичних грошах (монети чи золоторесурс казни), а з урахуванням індексу і ринкових цін. Це, за визначенням Л. М. Юровського, був так званий товарний карбованець, який став основою формування бюджету. Отже, розрахунки видаткової частини бюджету здійснювалися у довоєнних карбованцях, але за відповідним курсом. Такий карбованець вважали «індексним карбованцем», називаючи його «довоєнним карбованцем» або «довоєнним золотим карбованцем», тому він претендував на статус відповідної грошової одиниці 1913 року. Однак, ВЦВК та РНК РСФРР скасували 30 березня 1922 р. розрахунки у довоєнних грошах для державного i місцевих бюджетів, запровадивши радянські знаки [11, с. 198]. Така організаційно-технічна система розрахунків була громіздкою і фінансово нестійкою. Не випадково в обігу почали 3'являтися монети золотого карбування та іноземна валюта. Останні набували поширення, загрожуючи офіційним грошам, а відтак, - економічній стабільності.

Проте необхідність термінового проведення реформи грошової одиниці спонукали не золоті монети та інвалюта, які почали застосовувати майже напівлегально в обігу, а проблеми макроекономічного рівня. Свого відновлення потребувало народне господарство, державний сектор економіки, існувала нагальна потреба у формуванні стабільної бюджетної системи. «Держава, - як зазначав Л. М. Юровський, - не могла, за величезного бюджетного дефіциту, відмовитися від казначейської емісії паперових грошей, але вона змушена була зробити суттєвий крок у напрямку перетворення системи грошового обігу i дати господарському оборотові стійку валюту. Цей крок зроблено у вигляді надання емісійного права Державному банку. Так виник червінець» $[24$, с. 70]. Л. М. Юровський ототожнював запровадження червінця 3 грошовою реформою, але суть в іншому: право емісії для регулювання дефіциту бюджету передавали Держбанку. Червінець, який був банківським білетом, випускали для забезпечення комерційних, а не простих обмінних операцій. Між червінцями і радянськими знаками не було змістового зв'язку. 


\section{EKOHOMIKA}

Однак зв'язок червінця був із довоєнною грошовою одиницею, - він дорівнював 10 крб. старої золотої монети. «Твердість» червінця полягала в тому, що він став мірилом вартості, одиницею курсового обміну, охоплюючи іноземну валюту, міг бути конвертований у золото. Практично, крім еквівалента золотої монети дореволюційного карбування, червінці мали банківське забезпечення: $25 \%$ коштовними металами та інвалютою, а решту - короткотерміновими векселями на товари.

Червінці виходили номіналом банківських білетів 1, 2, 3, 5, 10, 25 і 50, кожен з яких дорівнював 78,24 долям чистого золота [13, с. 26]. Проте це була не золота валюта, а «валюта із золотим курсом», тому що не існувало прямого і вільного обміну червінців на золото. Різні фінансові джерела забезпечення червінця (коштовності, валюта і векселі промислових підприємств) дозволяли їх різне тлумачення. Поскільки векселі становили $75 \%$ гарантій, вважалося, що банкноти спиралися не на золотий запас Держбанку, а на товарні резерви підприємств, які мали цінове вираження. Тому використовували назву «товарний карбованець». Загалом вплив червінця на формування доходів державного бюджету був опосередкований. Вимога Держбанку про виняткове комерційне, а не казначейське використання червінця означала усунення його із бюджетного процесу. Хоча Держбанк мав право (але тільки $з$ дозволу уряду) давати позику Наркомфіну, проте під заставу - не менше 50 \% боргу забезпечувалися коштовними металами [24, c. 71]. Отже, значення червінця для бюджету полягало у загальній стабілізації грошової та фінансової систем, а конкретний вплив залежав від ролі та місця червінця у зростанні купівельної спроможності населення, піднесенні економічного розвитку, поліпшенні роботи податкових органів.

Ідейним батьком твердої валюти, тобто червінця, фактично був нарком фінансів Г. Я. Сокольніков. 6 січня 1922 р. «Экономическая газета» опублікувала його статтю «Гарантований карбованець». Він виклав суть одночасного введення ще одних паперових грошей - символічного «золотого довоєнного карбованця у банківському білеті Держбанку», який підлягав обміну на радянські грошові знаки. «Створення такого гарантованого карбованця, - писав він, - можливо шляхом «матеріалізації», втілення у паперовому грошовому знакові того умовного довоєнного (золотого) карбованця, в якому розраховано бюджет 1922 року, у якому встановлено ставки податку, у якому встановлено ціни продукції дер- жавних трестів, у якому запропоновано встановити ставки з.Д. тарифів і т.д. Довоєнний карбованець, як умовна одиниця (символ) грошового обліку і розрахунків, отримав уже повне право громадянства в нашій грошовій системі» [14]. Необхідність запровадження нової грошової одиниці з гарантованим матеріальним забезпеченням, про яке тоді говорив Г. Я. Сокольніков, активно обговорювалася в Інституті економічних досліджень Держплану, на нарадах у НКФ СРСР. Активну участь у дискусіях із цього питання брали номенклатурні працівники й теоретики Л.М.Юровський, А. А. Соколов, А. Г. Хрущов, 3. С. Каценеленбаум, В.В.Тарновський, Л.С.Ельяссон, П. П. Гензель, М. М. Шапошніков. Думки висловлювалися різні: одні виступали за зміцнення існуючих паперових грошей, інші - за створення нової грошової одиниці. Основна увага зосереджувалася на матеріальному забезпеченні оптимальної радянської валюти, якою став червінець. Однак перші кроки 3 його впровадження та подальша практика виявилися суперечливими, передусім у царині бюджетних відносин. Для них основним мірилом залишалися довоєнні золоті карбовані, «товарні рублі», «золоті рублі», тобто умовні гроші, але в реальних номіналах казначейських білетів 1922 та 1923 років випуску.

Випуск першої партії банківських банкнот за листопад - грудень 1922 p. становив 356 тис. червінців, у січні 1923 р. - 812 тис., за лютий червень - 6,6 млн, у липні - близько 4 млн, у серпні - 4,9 млн, у вересні - 5,9 млн, у січні 1924 р. - 2,3 млн червінців [25, с. 73]. Значні коливання у випуску червінців улітку 1923 р. зумовлювалися необхідністю кредитування промисловості, аби збільшити виробництво товарів для обміну на хліб нового врожаю. На 1 березня 1923 р. червінці становили $80 \%$, радянські знаки Наркомфіну СРСР - $8 \%$, транспортні сертифікати $-5,3 \%$, білети державної скарбниці $-5,4 \%$, срібні монети - $1 \%$ [19]. Поява твердої валюти сприяла витісненню натуральних кредитів початку 1920-х pp. і активізації грошових, зростанню їх фінансової ефективності, збільшенню питомої ваги довготривалих кредитів. Отже, червінець оздоровив фінансову систему, однак банківське кредитування представляло інше джерело розвитку економіки порівняно з бюджетним.

Функціональне значення грошової реформи, тобто впровадження твердої радянської валюти, а $з$ лютого 1924 р. - білетів державної скарбниці вартістю 1, 3, 5 карбованців золотом та розмінної срібної та мідної монет, полягало в упорядкуванні не лише платіжного засобу, а певною 


\section{EKOHOMIKA}

мірою й бюджету. Купівельна спроможність червінця, його здатність до обміну на іноземну валюту поступово зростали. Проте недорід 1924 р., коли виросли ціни на сільськогосподарську продукцію, похитнув позиції цієї грошової одиниці [12, с. 16]. «Золотий дукат», як називав Д. Кейнс червінець, завоював поважне місце в системі грошового обігу, витіснив «радзнаки», набув основного ціннісного мірила та платіжного засобу. Під кутом зору бюджетного фінансування основне навантаження протягом 19211924 рр. узяв на себе радянський знак («радзнак»), тобто гроші державної скарбниці. Радянський знак навіть охороняв червінець від знецінення в період його запровадження як нової грошової одиниці. Тому, визначаючи вплив грошової реформи на бюджетний процес, треба брати до уваги всі стадії грошової реформи та співвідношення довоєнного рубля і так званого товарного, умовного золотого рубля.

Загалом завершення грошової реформи радянська влада пов'язувала 31924 р., тобто з утвердженням червінця. Підсумовуючи іiі фінансовоекономічні та політичні наслідки, керівник Агітпропу ЦК РКП(б) О. І. Стецький сподівався, що «паперово-грошовий хаос», який тривав майже 8 років, завершився. Він не поділяв думку тих фахівців, які виокремлювали лише технічну складову реформи. «Але у тому й справа, - наголошував він у 1924 р., - що наша реформа ніяк не становить собою лише технічну операцію: вона $є$ наслідком цілої низки економічних і фінансових заходів Радянської влади протягом двох останніх років. Перехід до твердого золотого розрахунку, організація кредиту і банківської справи, податкова політика і скорочення дефіциту - ось окремі ланки того ланцюга заходів, які підвели нас до твердої валюти» [18, с. 39]. Стійка грошова одиниця мала безпосередній стосунок до кредитно-банківської справи, до податкової і бюджетної систем, сприяла утвердженню стійких бюджетних відносин.

Виваженою й об'єктивною виявилася оцінка грошової реформи, висловлена Г. Я. Сокольніковим. Бюджетний 1924/25 рік був несприятливим для червінця, тому що недорід розбалансував ціни, частково зменшив його купівельну спроможність. Однак бюджет формували без урахування паперової емісії. Водночас дефіцит бюджету сягнув 120 млн крб., його покривали за рахунок банківського кредиту, тобто у червінцях, і державної позики. Однак, незважаючи на запевнення у беземісійності покриття дефіциту бюджету, Держбанк СРСР змушений був випустив 80 млн крб. мідних монет [15, с. 47]. Відмо- витися від емісії було важко, навіть в умовах запровадження твердої валюти - червінця. Для Наркомфіну СРСР та банківської системи було важливим уберегти його від знецінення, унеможливити від ролі емісійного засобу. Для цього, на переконання Г.Я. Сокольнікова, треба було уникати емісії в доходах бюджету, економно використовувати його видатки, відповідально ставитися до бюджетного планування, ретельно розглядати фінансові джерела. Нарком фінансів СРСР не вважав скорочення бюджетного дефіциту головним успіхом грошової реформи, оскільки він не перешкоджав іiі здійсненню. Якщо місячна емісія не перевищувала 15 млн крб. нічого загрозливого для бюджету i фінансів не було, а проблема виникала у джерелах фінансування промисловості й транспорту. Позиція Г. Я. Сокольнікова 3 цього питання виявилася принциповою: фінансування промисловості й транспорту має відбуватися через систему банківського кредиту, а не за рахунок державного бюджету [16, с. 13-14]. Отже, червінець спрямовували на капітальне будівництво, зовнішньоекономічні операції, а білети державної скарбниці - для покриття дефіциту бюджету. Якщо ж Наркомфін СРСР і брав позику Держбанку у червінцях, то мав розраховувати на власні валютні резерви.

Грошова реформа (якщо брати до уваги не організаційно-технічну, а функціональну складову) не завершилася у 1924 р., тому що механічна заміна радянських грошових знаків на червінець не вирішувала базових проблем бюджетної системи. Грошова реформа сприяла впорядкуванню бюджетних відносин, особливо розрахунків державного та місцевих бюджетів. Водночас реальне наповнення доходної частини бюджетів залежало від загального економічного розвитку та багатьох інших фінансово-господарських факторів. Червінець захищали золотовалютними резервами, оберігали його від негативного впливу дефіциту бюджету, тому застосовували систему державної позики. Питання про золотовалютне забезпечення червінця досить активно обговорювалося на політбюро ЦК ВКП(б) 11 січня 1926 року. На його захист стали Г. Я. Сокольніков, Л. М. Юровський, О. І. Риков. Проти виступав Л. Д. Троцький, який не вважав збереження стабільності радянської валюти самоціллю, тому що для неї було байдуже, яка господарська основа переважала: приватнокапіталістична чи державно-соціалістична [17, с. 575]. За таких умов зміцнення червінця, на переконання колишнього «демона революції», сприяло непману, приватному капіталу, а не розвитку 


\section{EKOHOMIKA}

промисловості. Насправді тверда валюта упорядкувала кредитну систему, без якої державна промисловість не могла б відновити виробничого потенціалу.

Недорід 1924 р. продемонстрував вкрай хитку позицію радянського «золотого дуката», який залежав від резервних фондів Наркомфіну СРСР, державної скарбниці, коливань економічного розвитку. На подолання скрути, що виникла внаслідок неврожаю, довелося запустити механізм емісії. Випустили 100 млн крб. золотом, сподіваючись на покриття з боку торгівлі. Та цього не сталося, тому почали збільшувати видобуток золота.

У 1924 р. було видобуто 529 тис., у 1925 р. 778 тис., у 1926 р. - 1,1 млн пудів золота на копальнях Сибіру та Далекого Сходу [2]. Його було недостатньо, тому 23 вересня 1924 р. РНК СРСР видав постанову «Про заходи до піднесення державної і приватної золотопромисловості», зобов' язавши фінустанови скуповувати золото у населення за ціною 1 крб. 29 коп. за грам металу 1000 проби [4].

В УСРР діяли приватні «золото-срібляні промисловці», тобто ювеліри. Вони мали власні годинникові майстерні, магазини коштовних виробів, які підлягали реєстрації в округових пробірних управліннях. У списках «золотих майстрів» 1922 р. нараховувалося декілька сотень підприємців [20, арк. 1].

Загалом продукція приватної промисловості у $1926 / 27$ р. становила близько 4 \% від загальної вартості всієї продукції в УСРР [21, арк. 15]. Приватний капітал посідав $39 \%$ серед орендарів металопромисловості [24, арк. 6], але це була обробка металу, а не ювелірна справа.

Дозвіл закупівель золота свідчив про бідність державного золотого резерву, про брак належної і сталої бази для підтримки червінця. Державний запас «твердого золота» становив 180 млн крб, тому Г. Я. Сокольніков пропонував, аби «підтримати золоте забезпечення банкноти», продати за кордоном золота на 160 млн, а також реалізувати музейні коштовності в Голландії, скоротити видаткову частину бюджету тощо. Зменшення золотовалютного запасу відбувалося через те, що видобуте золото відразу спрямовувалося на погашення емісії.

Начальник Валютного управління НКФ СРСР Л. М. Юровський змушений був констатувати факт платіжної кризи перед західними кредиторами, позаяк дефіцит становив 50 млн валютних карбованців. Голова Раднаркому СРСР О. І. Риков навіть допускав можливість реальної інфляції, оскільки валютний резерв Наркомфіну становив 1 січня 1925 р. 8,2 млн, а 1 січня 1926 р. 333 тис. крб., золота у Держбанку залишалося 14-18 млн крб. [17, с. 570]. Радянська валюта втрачала фінансову «твердість». Задля ii реанімації пропонували «ущільнити бюджет під кутом зору індустріалізації», хоча були думки про використання експорту для зміцнення доходної частини бюджету.

Л. М. Юровський, який особисто долучився до творення червінця, вважав обов'язковим збереження його паритету по відношенню до іноземної валюти. Голова Держплану СРСР І. Т. Смілга повідомляв у січні 1926 р. Й. Сталіна про необхідність скорочення «споживчих витрат» державного бюджету, а також фінансування сільського господарства. Він вважав за необхідне збільшити експорт, аби забезпечити валютну складову червінця, який став символом фінансово-економічної стабільності.

Проте фактичне становище радянського «золотого дуката» було менш оптимістичним. «Якщо в очах населення червінець втратить значення твердої валюти, - наголошував Л. М. Юровський на засіданні Політбюро ЦК ВКП(б) 11 січня 1926 р., - то тоді ті червінці, які зараз є в кишенях, усі вони будуть викинуті на ринок» [17, c. 595].

Він боявся такого сценарію, тому що настав би крах грошового обігу і розпочався «товарний голод» - нестача промислових товарів для забезпечення грошової маси.

Наприкінці 1920-х рр. спостерігалося зниження купівельної спроможності червінця, але збільшувалися бюджетні асигнування, джерела яких мали податкове походження.

Висновки. Отже, грошова реформа сприяла подоланню дефіциту бюджету, проте не усунула самих емісійних джерел.

Вплив останньої на бюджет був опосередкований, позаяк нова радянська валюта мала вплив на стабілізацію кредитно-банківської системи, тобто й на фінансування промисловості, транспорту, що полегшувало бюджетне навантаження.

Як бачимо становлення та функціонування радянської бюджетної системи в УСРР у 1920ті pp. було неможливим без грошової реформи.

Ії здійснення у 1922-1924 рр. сприяло формуванню сталих показників доходної і видаткової частин державного і місцевих бюджетів, тобто так званого твердого бюджету.

Грошова реформа створювала передумови для загального розвитку економіки, відтак, для стабілізації та зміцнення бюджетних відносин. 


\section{БІБЛІОГРАФІЯ}

1. Бюджетний кодекс України від 8 липня 2010 року №2456 - VI. - Режим доступу: http://zakon2.rada.gov.ua/laws/show/2456-17

2. Дербер П. Наша золотопромышленность / П. Дербер // Экономическое обозрение. - 1924. № 13. - С. 61-67.

3. Історія народного господарства Української РСР. - У трьох томах, чотирьох книгах. - Т. 2. К. : Либідь, 1984.

4. Известия. - 1924. - 6 ноября.

5. Кейнс Дж.-М. Трактат о денежной реформе / Кейнс Дж.-М. - М. : Изд-во «Экономическая жизнь», 1925. - $108 \mathrm{c}$.

6. Лазур М. П. Фінансово-економічні зміни в УСРР в умовах непу 1921-1929 рр.: історіографія / М. П. Лазур: автореф. дис. ... канд. іст. наук по спец.: 07.00.06 - «Історіографія, джерелознавство та спеціальні історичні дисципліни». Переяслав-Хмельницький, 2011. - 24 с.

7. Новиикий А. Роль эмиссии в государственном бюджете / А. Новицкий // Финансовый бюллетень. - 1923. - № 4. - С. 2.

8. Полімук B. I. Грошова реформа в Україні в роки непу / В. І. Поліщук : автореф. дис. ... канд. екон. наук. по спец.: 08.01.04 - «Економічна історія та історія економічної думки». - К., 1996. $17 \mathrm{c}$.

9. Преображенский Е. Бумажные деньги в эпоху пролетарской диктатуры / Евгений Преображенский. - М. : Экономическая жизнь, 1920. $54 \mathrm{c}$.

10. Рейнольд И. К эволюции государственого бюджета СССР / И. Рейнольд // Большевик. 1924. - № 9. - С. 2.

11. Свод общегосударственных доходов и расходов по росписи на 1922-1923 бюджетный год в золотых рублях // Финансовый бюллетень. 1923. - № 5-6. - С. 3-21.

12. Сигал Б. В. Денежное обращение на Украине в 1924-25 году / Б. В. Сигал // Экономический бюлетень. - 1925. - № 10-11.

13. Соболев М. Н. Система нашего денежного обращения и ее завершение / М.Н. Соболев // Хозяйство Украины. - 1925. - № 3-4.

14. Сокольников Г. Я. Гарантированный рубль / Г. Я. Сокольников // Экономическая жизнь. 1922. - 6 января.

15. Сокольников Г. Бюджет и валюта / Григорий Яковлевич (Гирш Янкелевич) Сокольников. М. : Экономическая жизнь, 1924. - 90 с.

16. Сокольников Г.Я. Денежная реформа / Григорий Яковлевич Сокольников. - М., 1925. $194 \mathrm{c}$.

17. Стенограммы заседаний политбюро ЦК РКП(б)-ВКП(б). 1923-1938. - В трех томах. Т. 1. 1923-1926 / Ред. совет изд.: К. М. Андерсон, А. Ю. Ватлин, П. Грегори. - М., 2007.

18. Стецкий А. Завершение денежной реформы / А. Стецкий // Большевик. - 1924. - № 4-5. C. 3 .

19. Фихман Б. Денежное обращение в январефеврале 1924 г. / Б. Фихман // Экономическое обозрение. - 1924. - № 7. - С. 55-62.

20. ЦДАВО України. - Ф. 30. - Оп. 1. Спр. 897.

21. ЦДАВО України. - Ф. 2623. - Оп. 1. Спр. 3307.

22. ЦДАВО України. - Ф. 337. - Оп. 1. Спр. 6707.

23. ЦДАГО України. - Ф. 1. - Оп. 20. Спр. 1889.

24. Юровский Л. Н. На путях к денежной реформе / Леонид Наумович Юровский. - М. : Финансовое издательство, 1924. - $117 \mathrm{c.}$

25. Юровский Л. Н. Денежная политика советской власти (1917-1927) / Леонид Наумович Юровский. - М. : Финансовое издательство, 1928. $401 \mathrm{c}$.

26. Яснопольский Л. Эмиссия в 1921/22 г., 1922/23 г. / Л. Яснопольский // Хозяйство Украины. - 1923. - № 1. - С. 3-6.

27. Яснопольский Л. Новая фаза нашей эмиссии / Л. Яснопольский // Хозяйство Украины. 1923. - № 3. - С. 1-4. 